\title{
Effect of soil conditioners on the chemical attributes of a saline-sodic soil and on the initial growth of the castor bean plant
}

\section{Uso de condicionadores nos atributos químicos de um solo salino- sódico e no crescimento inicial de mamoneira}

\author{
Evandro Franklin de Mesquita ${ }^{1}$; Francisco Vanies da Silva Sá ${ }^{2}$; \\ Antônio Michael Pereira Bertino ${ }^{3}$; Lourival Ferreira Cavalcante ${ }^{4}$; \\ Emanoela Pereira de Paiva $^{5}$; Nubia Marisa Ferreira ${ }^{3}$
}

\begin{abstract}
This work aimed to study the effect of chemical and organic conditioners on the chemical attributes of a saline-sodic soil and on the initial growth of two castor bean cultivars. Two experiments were performed in the green house of the Center of Human and Agrarian Sciences of the Paraíba State University (CCHA-UEPB), Campus IV, Catolé do Rocha-PB. In the first experiment, an entirely randomized experimental design with five treatments [(saline - sodic soil without conditioners (SSC), saline - sodic soil + biofertilizer at $10 \%$ of the soil volume ( $\mathrm{SS}+\mathrm{B}$ ), saline - sodic soil + chalk at $100 \%$ of the chalk requirement $(\mathrm{SS}+\mathrm{C})$, saline - sodic soil + chalk + biofertilizer $(\mathrm{SS}+\mathrm{C}+\mathrm{B})$, and non-saline soil (NSL)] and eight replicates was adopted. In the second randomized experiment the treatments were displayed in a $5 \times 2$ factorial scheme, referring to the five corrective treatments used in the first experiment and the two castor bean plant cultivars (BRS Nordestina and BRS Paraguaçu), with four replicates. The application of chalk combined with biofertilizer promoted a better initial development of the castor bean plant in comparison with other recovering treatments. This indicates the corrective effect of chalk on sodicity and of both treatments on the nutrient availability for the plants. The bovine biofertilizer alone did not reduce the sodicity of the sodic - saline soil. Under the evaluated conditions, the BRS Nordestina surpassed the BRS Paraguaçu.
\end{abstract}

Key words: Ricinus communis L., salinity, sodicity, soil correction

\section{Resumo}

O objetivo do trabalho foi estudar a aplicação de condicionadores de natureza química e orgânica nos atributos químicos de um solo salino-sódico e no crescimento inicial de duas cultivares de mamoneira. Dois experimentos foram conduzidos em casa de vegetação do Centro de Ciências Humanas e Agrárias da Universidade Estadual da Paraíba (CCHA-UEPB), Campus IV, Catolé do Rocha-PB. No primeiro experimento adotou-se o delineamento experimental inteiramente casualizado com cinco tratamentos

\footnotetext{
1 Eng ${ }^{\circ}$ Agr $^{\circ}$, Prof. Dr., Dept ${ }^{\circ}$ de Agrárias e Exatas, Universidade Estadual da Paraíba, UEPB, Catolé do Rocha, PB, Brasil. E-mail: elmesquita4@uepb.edu.br

2 Mestrando em Manejo de Solo e Água, Universidade Federal Rural do Semi-Árido, UFERSA, Mossoró, RN, Brasil. E-mail: vanies_agronomia@hotmail.com

3 Mestrandos em Agronomia, Universidade Federal da Paraíba, Areia, PB, Brasil. E-mail: ampbantonio@gmail.com; nubiamarisa1@, hotmail.com

4 Eng $^{\mathrm{o}} \mathrm{Agr}^{\mathrm{o}}$, Prof. Dr., Dept ${ }^{\mathrm{o}}$ de Solo e Engenharia Rural, Universidade Federal da Paraíba, UFPB, Areia, PB, Brasil. Bolsista de Produtividade em Pesquisa do CNPq. E-mail: lofeca@cca.ufpb.br

5 Eng $^{\mathrm{a}}$ Agr ${ }^{\mathrm{a}}$, Discente do Curso de Doutorado em Fitotecnia, Universidade Federal Rural do Semi-Árido, UFERSA, Mossoró, RN, Brasil. E-mail: emanuelappaiva@hotmail.com

* Author for correspondence
} 
(Solo salino - sódico sem corretivo (SSC), Solo salino - sódico + biofertilizante à $10 \%$ do volume do solo $(\mathrm{SS}+\mathrm{B})$, Solo salino - sódico + gesso à $100 \%$ da necessidade de gesso $(\mathrm{SS}+\mathrm{G})$, Solo salino - sódico + gesso + biofertilizante ( $\mathrm{SS}+\mathrm{G}+\mathrm{B})$ e solo não salino (SNS)) com 8 repetições e, no segundo experimento, também conduzido em delineamento inteiramente casualizado, os tratamentos foram arranjados em esquema fatorial $5 \times 2$, referente aos cinco tratamentos de correção obtidos no primeiro experimento e duas cultivares de mamoneira (BRS Nordestina e BRS Paraguaçu), com quatro repetições. A Aplicação de gesso associado ao biofertilizante promoveu o maior desenvolvimento inicial das plantas de mamoneira quando comparado aos demais tratamentos de recuperação e indica ação positiva do gesso como corretivo da sodicidade e de ambos no aumento da disponibilidade de nutrientes às plantas. $\mathrm{O}$ biofertilizante bovino isolado não reduz a sodicidade do solo salino - sódico. Nas condições estudadas, a cultivar BRS Nordestina superou a BRS Paraguaçu.

Palavras-chave: Ricinus communis L., salinidade, sodicidade, correção de solo

\section{Introduction}

The castor bean plant (Ricinus communis L.), a member of the Euphorbiaceae family, is an oleaginous plant included in the National Program for Biodiesel Production and Use, whose socioeconomic value is likely to increase in the future. Currently, it is characterized as a low-productivity culture in extensive cultivation due to lack of technologies to ensure an economically viable yield potential, especially with regard to irrigation and fertilization (SOUZA et al., 2007). In addition to these limitations, there are salinity and sodicity risks in semi-arid regions. Analyzing castor bean hybrids under conditions of high matric potentials, Babita et al. (2010) observed significant decreases in grain production and seed oil content.

In irrigated semi-arid regions where water use is not strictly controlled, salinity and sodicity are the main factors responsible for the loss of soil productivity potential, resulting in serious socio-economic and environmental problems (RICHARDS, 1954; SANTOS et al., 2005; NEVES et al., 2009).

In areas where the atmospheric requirements are higher than rainfall, soil salinity issues are frequent, especially in the context of crystalline rocks. Salinity-affected soils are characterized by elevated concentrations of soluble salts, exchangeable sodium, or both (BARROS et al., 2004; CAVALCANTE et al., 2005). According to Munns and Tester (2008), the specific effects of excess sodium and chlorine salts hamper high agricultural production, mainly due to the reduced osmotic potential of the soil solution and the consequent toxicity to the plants. The reduction of environmental and social impacts caused by excess water-soluble and exchangeable sodium salts in irrigated, previously productive areas requires the use of reclamation techniques, based on the addition of chalk and organic compounds, to obtain chemical and physical improvements as well as salt lixiviation, to restore the productivity of the soil (LEITE et al., 2010).

To correct saline-sodic and sodic soils, excess exchangeable sodium in the soil sorption complex must be substituted by the calcium released by chemical conditioners, such as chalk, and the product of this reaction must be eliminated from the root proximity by lixiviation (RICHARDS, 1954; BARROS et al., 2005). Chemical conditioners such as chalk, sulfuric acid, elementary sulfur, and organic matter have been used widely and successfully to minimize salinity and sodicity of irrigated soils (QADIR et al., 2007; MENEZES JUNIOR et al., 2010; SOUSA et al., 2012; SÁ et al., 2013a). The chemical improvement reflects a decrease in salinity expressed by the reduced electrical conductivity of the saturated extract and less sodicity due to lower percentages of exchangeable sodium. The physical improvement of the structure and the porous space results in increased drainage for salt lixiviation, maintaining plant-tolerable salt levels in the soil (SUAREZ, 2001; SÁ et al., 2013b). 
According to Freire and Freire (2006), organic conditioners (farmyard manure, rice husk, and vinasse) can also contribute to reducing the sodicity expressed by the exchangeable sodium percentage (ESP) due to the release of $\mathrm{CO}_{2}$ and organic acids during decay of organic matter. They are also a source of calcium and magnesium. Paixão et al. (2013) observed positive responses to bovine manure in the development of castor bean plants irrigated with saline water. Li-yuan et al. (2013) reported that organic matter reduced the effect of saline stress in castor bean plants grown in sodicsaline soils.

Considering the above, the aim of this work was to study the effects of chemical and organic conditioners on the chemical attributes of a salinesodic soil and on the initial growth of two castor bean plant cultivars.

\section{Material and Methods}

Two experiments were performed in the green house of the Center of Human and Agrarian Sciences of the Paraíba State University (CCHA-UEPB), Campus IV, Catolé do Rocha-PB, using samples from a saline-sodic soil and a non-saline soil. Both samples were obtained from the $0-20 \mathrm{~cm}$ soil layer. The sodic-saline soil sample was from the Nucleus 1 of the São Gonçalo Irrigated Perimeter, located 10 $\mathrm{km}$ from the Sousa municipality, PB, while the nonsaline sample soil was from the Olericulture sector of the State University of Paraíba (CCHA-UEPB), Campus IV, Catolé do Rocha-PB. Both soils were classified as entisol (EMBRAPA, 2006).

After air-drying, the samples were crushed, passed through a sieve with a $2.0 \mathrm{~mm}-\mathrm{mesh}$, and sent to the Laboratory of Soil Analyses of the Center of Technology and Natural Resources - CTRN of the Federal University of Campina Grande UFCG, for physical and chemical characterization (Table 1) according to the methodology described by Bonagema et al. (2011).

Table 1. Chemical attributes of a saline - sodic soil from the municipality of Sousa - PB and of a non-saline soil of the municipality of Catolé do Rocha-PB. Catolé do Rocha-PB, 2014.

\begin{tabular}{|c|c|c|c|c|c|}
\hline Exchangeable & $\begin{array}{c}\text { Saline-sodic } \\
\text { soil }\end{array}$ & $\begin{array}{c}\text { Non-saline } \\
\text { soil }\end{array}$ & Soluble & $\begin{array}{c}\text { Saline-sodic } \\
\text { soil }\end{array}$ & $\begin{array}{c}\text { Non-saline } \\
\text { soil }\end{array}$ \\
\hline $\mathrm{pH}\left(\mathrm{CaCl}_{2}\right)$ & 9.96 & 7.06 & $\mathrm{CE}_{\mathrm{es}}\left(\mathrm{dS} \mathrm{m} \mathrm{m}^{-1}\right)$ & 24.38 & 0.32 \\
\hline $\mathrm{P}\left(\mathrm{mg} \mathrm{kg}{ }^{-1}\right)$ & 0.64 & 53.40 & $\mathrm{pH}_{\mathrm{es}}$ & 10.29 & 6.89 \\
\hline $\mathrm{K}^{+}\left(\mathrm{cmol}_{\mathrm{c}} \mathrm{dm}^{-3}\right)$ & 0.23 & 0.76 & $\mathrm{Ca}^{2+}+\mathrm{Mg}^{2+}\left(\mathrm{mmol}_{\mathrm{c}} \mathrm{L}^{-1}\right)$ & 0.60 & 12.50 \\
\hline $\mathrm{Na}^{+}\left(\mathrm{cmol}_{\mathrm{c}} \mathrm{dm}^{-3}\right)$ & 22.96 & 0.30 & $\mathrm{Na}^{+}\left(\mathrm{mmol}_{\mathrm{c}} \mathrm{L}^{-1}\right)$ & 201.30 & 3.66 \\
\hline $\mathrm{Ca}^{2+}\left(\mathrm{cmol}_{\mathrm{c}}^{\mathrm{c}} \mathrm{dm}^{-3}\right)$ & 0.40 & 4.63 & $\mathrm{~K}^{+}\left(\mathrm{mmol}_{\mathrm{c}}^{\mathrm{c}} \mathrm{L}^{-1}\right)$ & 0.88 & 2.46 \\
\hline $\mathrm{Mg}^{2+}\left(\mathrm{cmol}_{\mathrm{c}} \mathrm{dm}^{-3}\right)$ & 0.00 & 2.39 & $\left.\underline{\operatorname{SAR}(m m o l ~ L})^{-1}\right)^{-0,5}$ & 121.40 & 1.46 \\
\hline $\mathrm{H}+\mathrm{Al}\left(\mathrm{cmol}_{\mathrm{c}} \mathrm{dm}^{-3}\right)$ & 0.00 & 0.00 & Granulometry & Saline -sodic & Non-saline \\
\hline $\mathrm{SB}\left(\mathrm{cmol}_{\mathrm{c}} \mathrm{dm}^{-3}\right)$ & 23.59 & 8.08 & Sand $\left(\mathrm{g} \mathrm{kg}^{-1}\right)$ & 650 & 675 \\
\hline CTC $\left(\mathrm{cmol}_{\mathrm{c}} \mathrm{dm}^{-3}\right)$ & 23.59 & 8.08 & Silt $\left(\mathrm{g} \mathrm{kg}^{-1}\right)$ & 255 & 272 \\
\hline M.O. $\left(\mathrm{g} \mathrm{kg}^{-1}\right)$ & 2.00 & 18.80 & Clay $\left(\mathrm{g} \mathrm{kg}^{-1}\right)$ & 95 & 53 \\
\hline V (\%) & 100.00 & 100.00 & & & \\
\hline $\operatorname{ESP}(\%)$ & 97.32 & 3.71 & & & \\
\hline
\end{tabular}

$\mathrm{P}, \mathrm{K}, \mathrm{Na}-$ Mehlich extraction 1; $\mathrm{Al} 3+, \mathrm{Ca} 2+, \mathrm{Mg} 2+-$ extractor $\mathrm{KCl} 1,0 \mathrm{~mol} \mathrm{~L}-1 ; \mathrm{SB}=\mathrm{Ca} 2++\mathrm{Mg}+2+\mathrm{K}++\mathrm{Na}+; \mathrm{H}++$ $\mathrm{Al} 3+$ : Extractor calcium acetate $0,5 \mathrm{~mol} \mathrm{~L}-1, \mathrm{pH} 7,0 ; \mathrm{CTC}=\mathrm{SB}+(\mathrm{H}++\mathrm{Al}+3)$; M.O.: Walkley - Black Humid Digestion; ESP= Exchangeable Sodium Percentage $(\mathrm{Na}+/ \mathrm{CTC}) 100 ; \mathrm{RAS}=$ Sodium adsorption ratio $\mathrm{Na}+[(\mathrm{Ca} 2++\mathrm{Mg} 2+) / 2] 1$. 
In the first experiment, an entirely randomized experimental design with five treatments [(saline sodic soil without conditioners (SSC), saline - sodic soil + biofertilizer at $10 \%$ of the soil volume (SS + B), saline - sodic soil + chalk at $100 \%$ of the chalk requirement $(\mathrm{SS}+\mathrm{C})$, saline - sodic soil + chalk + biofertilizer ( $\mathrm{SS}+\mathrm{C}+\mathrm{B})$, and non-saline soil (NSL)] and eight replicates in a total of 40 experimental units was adopted. Each experimental unit consisted of two vases containing $2.0 \mathrm{dm}^{3}$ of soil. The amount of chalk to be added was calculated according to the method reported by Leite et al. (2007) using the formula $\mathrm{CR}=0.86 \mathrm{Na}^{+} \mathrm{x} /$ calcium sulfate purity, where: $\mathrm{CR}=$ chalk requirement in $\mathrm{g} \cdot \mathrm{kg}^{-1}$ soil; $\mathrm{Na}^{+} \mathrm{X}$ $=$ level of exchangeable sodium in cmolc. $\mathrm{dm}^{-3}$. The bovine biofertilizer was obtained by anaerobic fermentation during a 45-day incubation period for the fermentation of organic residues, bovine manure, and roots of a leguminous plant (Phaseolus vulgaris), whose chemical composition is indicated on Table 2.

Table 2. Chemical attributes of bovine fertilizer. Catolé do Rocha-PB, 2014.

\begin{tabular}{|c|c|c|c|c|c|c|c|c|c|c|}
\hline $\mathrm{pH}$ & $\mathrm{EC}$ & $\mathrm{Ca}^{2+}$ & $\mathrm{Mg}^{2+}$ & $\mathrm{Na}^{+}$ & $\mathrm{K}^{+}$ & $\mathrm{Cl}^{-}$ & $\mathrm{CO}_{3}^{2-}$ & $\mathrm{HCO}_{3}$ & $\mathrm{SO}_{4}^{2-}$ & $\mathrm{P}$ \\
\hline & $\mathrm{dS} \mathrm{m}^{-1}$ & & & & ... & $\mathrm{L}^{-1}$. & & & & $\left(\mathrm{mg} \mathrm{dm}^{3}\right)$ \\
\hline 6.34 & 0.81 & 2.71 & 1.04 & 3.27 & 1.19 & 4.59 & 0.43 & 2.03 & 1.02 & 56.00 \\
\hline
\end{tabular}

$\mathrm{EC}=$ electrical conductivity.

The vases used in the experiment were constructed following the model of the Leonard vases according to the methodology described by Santos et al. (2009), using $3 \mathrm{dm}^{3}$ pet bottles that were filled with $2 \mathrm{dm}^{3}$ of soil. This setup enabled the humidity levels to remain close to the field capacity levels throughout the experiment, with the use of a capillary water flow. The chalk was incorporated into the soil, and the biofertilizer was introduced by two equal applications, where the first $50 \%$ was added to the surface and the remaining $50 \%$ was added eight days after the experiment began.

After the conditioners were added, the soil samples were incubated for 45 days. Thirty days later the first lixiviation was performed with a water volume $\left(\mathrm{CEa}=0.3 \mathrm{dSm}^{-1}\right)$ corresponding to twice the total soil porosity (LEITE et al., 2007), followed by 15 days of incubation, after which the second round of lixiviation was performed following the same criteria, in order to reach the maximum lixiviation of salts.

After the second washing, a simple sampling was performed from the upper, middle, and lower layers of the soil contained in the vases. Those samples were mixed to form a composed sample for further chemical characterization. These included salinity measured by electrical conductivity of a saturated extract $\left(\mathrm{EC}_{\mathrm{se}}\right)$, levels of soluble $\mathrm{Na}^{+}, \mathrm{Ca}^{2+}, \mathrm{Mg}^{2+}$, and $\mathrm{K}^{+}$, and exchangeable sodium percentage (ESP), according to the methods described by Richards (1954).

In the second randomized experiment, the treatments were displayed in a factorial $(5 \times 2)$ manner, referring to the five treatments for the correction of sodicity [(saline - sodic soil without conditioners (SSC), saline - sodic soil + biofertilizer at $10 \%$ of the soil volume (SS $+\mathrm{B})$, saline - sodic soil + chalk at $100 \%$ of the chalk requirement (SS + C), saline - sodic soil + chalk + biofertilizer (SS + $\mathrm{C}+\mathrm{B}$ ), and non-saline soil (NSL)] used in the first experiment and the two castor bean cultivars, BRS Nordestina and BRS Paraguaçu, with four replicates in a total of 40 experimental units, each of which consisted of two vases containing one plant each.

Seeds were germinated in 128-cell trays filled with substrate consisting of non-saline soil (Table 
1). When the seedlings reached a $15 \mathrm{~cm}$ high, they were selected according to uniformity and transferred to the vases containing soil in the five previously described conditions. To evaluate the height increment, plants were measured at time zero. Before planting and after soil washing, a basic fertilization procedure with biofertilizers at $10 \%$ of the soil volume was performed (Table 2).

Thirty days after transfer (DAT), the heights of the seedlings were measured again, as well as the stem diameter, allowing the height/diameter ratio to be calculated. The number of leaves was counted and the foliar surface was estimated according to equation 1, as proposed by Wendt (1967). The foliar surface ratio was calculated by the ratio between the foliar surface and the dry matter of the aerial portion employing equation 2, as described by Sá et al. (2013b).

$$
\begin{gathered}
\mathrm{FS}=\Sigma\{-0,346+[2,152 \times \log (\mathrm{X})]\} \\
\text { FSR }=\frac{\text { FS }}{\text { DMAP }}
\end{gathered}
$$

Where: FS is the foliar surface $\left(\mathrm{cm}^{2}\right)$ and $\mathrm{X}$ the length of the central vase of the leaf $(\mathrm{cm})$;

FSR the foliar surface ratio $\left(\mathrm{cm}^{2} \cdot \mathrm{g}^{-1}\right)$ and DMAP the dry matter of the aerial part of the plants.
After growth analyses, the aerial portion (stem + leaves) and the roots of the castor bean plants were harvested individually and placed in a drying chamber with ventilation at $65^{\circ} \mathrm{C}$, to determine the dry matter of each part; the sum and the ratio between these values gave the total dry matter and the ratio root/aerial part, respectively.

Statistical evaluations were performed using the analysis of variance (ANOVA) with the ' $F$ ' test and Tukey's range test, at the 5\% significance level, using the Sisvar software version 5.0 (FERREIRA, 2011).

\section{Results and Discussion}

The different soil conditioners (Table 3) had significant effects on the following variables: electrical conductivity of a saturated extract $-\mathrm{EC}_{\mathrm{se}}$, $\mathrm{pH}$ level, levels of calcium, magnesium, sodium, and potassium, sodium adsorption ratio - SAR, and exchangeable sodium percentage - ESP ( $p$ $<0,01)$. The conditioners had a positive effect on the variables $\mathrm{pH}_{\mathrm{se}}, \mathrm{EC}_{\mathrm{se}}$, and ESP, because these respective variables are indicators of the levels of alkalinity $(\mathrm{pH})$ and salinity $\left(\mathrm{EC}_{\mathrm{se}}\right)$ as well as soil sodicity (ESP). The observed decrease in the levels of soluble salts in the soil was consistent with the reduction in $\mathrm{pH} . \mathrm{EC}_{\mathrm{se}}$, $\mathrm{SAR}$, and $\mathrm{ESP}$ values also indicate that there were positive effects in comparison with the initial conditions of salinity and sodicity indicated in Table 1 , as noted by Richards (1954).

Table 3. Summary of the analysis of variance of the variables electrical conductivity $\left(\mathrm{CE}_{\mathrm{es}}\right), \mathrm{pH}$, calcium, magnesium, sodium, potassium, sodium adsorption ratio (SAR), and exchangeable sodium percentage (ESP) of a saline-sodic soil as a function of the application of chemical and organic conditioners and lixiviation of a non-saline soil. Catolé do Rocha - PB, 2014.

\begin{tabular}{cccccccccc}
\hline SV & DF & \multicolumn{8}{c}{ QUADRATIC MEAN } \\
\cline { 3 - 9 } & & $\mathrm{pH}_{\mathrm{es}}$ & $\mathrm{CE}_{\mathrm{es}}$ & $\mathrm{Ca}^{2+}$ & $\mathrm{Mg}^{2+}$ & $\mathrm{Na}^{+}$ & $\mathrm{K}^{+}$ & $\mathrm{SAR}$ & ESP \\
\hline $\mathrm{C}$ & 4 & $7.13^{* *}$ & $43.40^{* *}$ & $750.24^{* *}$ & $206.49^{* *}$ & $5361.39^{* *}$ & $11.37^{* *}$ & $9128.59^{* *}$ & $3999.78^{* *}$ \\
Error & 28 & 0.16 & 0.26 & 1.63 & 3.43 & 27.04 & 0.02 & 3.18 & 0.99 \\
\hline $\mathrm{CV}$ & 4.71 & 11.81 & 12.29 & 33.95 & 11.16 & 18.57 & 5.44 & 3.83 \\
\hline
\end{tabular}

** and $\mathrm{ns}=$ significant at $1 \%$ and not significant, respectively; $\mathrm{SV}=$ source of variation; $\mathrm{DF}=$ degree of freedom; $\mathrm{C}=\mathrm{chemical}$ and organic conditioners; $\mathrm{CV}=$ coefficient of variation. 
According to the values shown in Table 4, the addition of the conditioners chalk and biofertilizer to a saline-sodic soil reduced the levels of soluble calcium, magnesium, sodium, and potassium. However, it was also observed that washing, regardless of conditioner application, was effective for reducing salinity and acidity of the salinesodic soil. This indicates that regardless of the addition of conditioners, washing was effective in the lixiviation of salts in all treatments; however, levels of sodium salts remained higher than those of other cations. The high SAR average value of 29.6 $\left(\mathrm{mmol} \cdot \mathrm{L}^{-1}\right)^{1 / 2}$, which was 40 times higher than the value observed for the non-saline soil, reflects the high level of sodicity with the treatments involving the saline-sodic soil.

Table 4. Tukey's range test on the variables electrical conductivity $\left(\mathrm{CE}_{\mathrm{es}}\right), \mathrm{pH}_{\mathrm{es}}$, calcium $\left(\mathrm{Ca}^{2+}\right)$, magnesium $\left(\mathrm{Mg}^{2+}\right)$, sodium $\left(\mathrm{Na}^{+}\right)$, potassium $\left(\mathrm{K}^{+}\right)$, sodium adsorption ratio (SAR), exchangeable sodium percentage (ESP), and soil classification according to the methodology used by Richards (1954), of a saline-sodic soil after the addition of chemical and organic conditioners, washing, and of a non-saline soil. Catolé do Rocha-PB, 2014.

\begin{tabular}{cccccccccc}
\hline Treatment & $\mathrm{pH}_{\mathrm{es}}$ & $\begin{array}{c}\mathrm{CE}_{\mathrm{es}} \\
\mathrm{dSm}^{-1}\end{array}$ & $\begin{array}{c}\mathrm{Ca}^{2+} \\
-----------------m m o l ~ \mathrm{~m}^{-1}--------------\end{array}$ & $\begin{array}{c}\mathrm{Mg}^{2+} \\
(\mathrm{mmol} \mathrm{L})^{-1}-5\end{array}$ & $\begin{array}{c}\mathrm{ESP} \\
\%\end{array}$ & Soil Class \\
\hline $\mathrm{SSC}$ & $9.20 \mathrm{a}$ & $2.32 \mathrm{c}$ & $1.08 \mathrm{~d}$ & $0.96 \mathrm{c}$ & $58.55 \mathrm{~b}$ & $0.14 \mathrm{c}$ & $58.03 \mathrm{~b}$ & $45.64 \mathrm{~b}$ & Sodic \\
$\mathrm{SS}+\mathrm{B}$ & $9.09 \mathrm{a}$ & $3.49 \mathrm{~b}$ & $1.45 \mathrm{~d}$ & $0.45 \mathrm{c}$ & $77.07 \mathrm{a}$ & $0.23 \mathrm{c}$ & $79.14 \mathrm{a}$ & $53.49 \mathrm{a}$ & Sodic \\
$\mathrm{SS}+\mathrm{C}$ & $8.95 \mathrm{a}$ & $7.04 \mathrm{a}$ & $22.45 \mathrm{a}$ & $7.16 \mathrm{~b}$ & $46.59 \mathrm{c}$ & $0.30 \mathrm{c}$ & $12.11 \mathrm{c}$ & $14.17 \mathrm{c}$ & Saline \\
$\mathrm{SS}+\mathrm{C}+\mathrm{B}$ & $8.16 \mathrm{~b}$ & $6.64 \mathrm{a}$ & $18.16 \mathrm{~b}$ & $5.83 \mathrm{~b}$ & $44.18 \mathrm{c}$ & $0.59 \mathrm{~b}$ & $12.79 \mathrm{c}$ & $14.91 \mathrm{c}$ & Saline \\
$\mathrm{NSS}$ & $6.95 \mathrm{c}$ & $2.25 \mathrm{c}$ & $8.76 \mathrm{c}$ & $12.87 \mathrm{a}$ & $6.55 \mathrm{~d}$ & $2.95 \mathrm{a}$ & $1.96 \mathrm{~d}$ & $1.60 \mathrm{~d}$ & Normal \\
\hline
\end{tabular}

*Non-saline soil (NSS); Saline - sodic soil without conditioners (SSC); Saline - sodic soil plus biofertilizer at $10 \%$ of the soil volume (SS+B); Saline - sodic soil plus chalk at $100 \%$ of chalk requirement $(\mathrm{SS}+\mathrm{C})$, Saline - sodic soil plus chalk and biofertilizer $(\mathrm{SS}+\mathrm{C}+\mathrm{B}) . * *$ Different letters in the columns indicate significantly different values according to the Tukey's test at the $5 \%$ significance level.

In the treatments with chalk, with or without addition of biofertilizer, the highest levels of soluble calcium, magnesium, and potassium, and the lowest levels of sodium were recorded, consequently resulting in the decrease of SAR and ESP in the sodic-saline soil (Table 4). Significant reductions in the salinity and sodicity caused by the addition of chalk and organic matter to salt-degraded soils were observed by Leite et al. (2007), Miranda et al. (2011), Sousa et al. (2012), and Sá et al. (2013b).

The highest reductions in soluble sodium concentration were attributed to the use of chalk with or without biofertilizer. However, the observed concentration, on average, was still six times higher than that observed for the non-saline soil (Table 4). This reduction in sodium levels, though modest, resulted in low values of $\mathrm{pH}$, SAR, and ESP. However, the electrical conductivity was still high, a fact attributed to the elevated concentrations of calcium and magnesium, as this soil lost its sodic character (Table 4). The $\mathrm{SS}+\mathrm{C}+\mathrm{B}$ treatment resulted in the lowest $\mathrm{pH}$ value observed for the saline-sodic soil, probably because the humic substances present in the organic matter contributed to the production of organic acids (NUNES et al., 2009), which, when associated with the high levels of calcium released by the solubilization of chalk and the lixiviation, caused the highest reduction of soil alkalinity (Table 4). The high calcium concentrations in the chalk favored the displacement of sodium from the sorption complex to the soil solution (QADIR et al., 2007), which is partially lixiviated by washing (LEITE et al., 2007; SOUSA et al., 2012; SÁ et al., 2013a).

The combination of chalk and biofertilizer led to improvements in the soil structure, resulting in 
a higher particle aggregation and in an increased availability of calcium, magnesium, and potassium in the soil, increasing competition with sodium and elevating their levels in the soil lixiviation solution after washing followed by drainage (MIRANDA et al., 2011; SOUSA et al., 2012; SÁ et al., 2013a).

As shown in Table 4, the soil treated without conditioners and only with biofertilizer changed from saline-sodic to sodic, that is, the correction capacity was lost. According to Richards (1954), Barros et al. (2005) and Leite et al. (2010), there was a reduction in the electrical conductivity of the saturated extract caused by lixiviation of soluble cations such as calcium, which substitutes $\mathrm{Na}^{+}$in the clay complex, resulting instead in increased sodicity. On the other hand, treatments with chalk with or without biofertilizer led to a marked reduction in the sodic character, and the soil changed from salinesodic to saline. Under these conditions, the electrical conductivity remained high, but the exchangeable sodium percentage - ESP was reduced and the sodicity issues, which are more severe than salinity for the soil and the plants (Miranda et al., 2011), were diminished. Washing the soil samples alone or in association with biofertilizer altered the soil classification from saline-sodic to sodic, which is an undesirable situation in the reclamation process.
In contrast, the application of chalk combined with washing, significantly reduced the soil sodicity, even though the salinity was increased. According to Freire and Freire (2006), the addition of chalk results in two chemical reactions in the soil: 1) $\mathrm{Ca}^{2+}$ ions substitute the $\mathrm{Na}^{+}$in the sorption complex, changing clay-Na into clay-Ca; 2) chalk tends to react with $\mathrm{Na}_{2} \mathrm{CO}_{3}$, originating $\mathrm{CaCO}_{3}$ and $\mathrm{Na}_{2} \mathrm{SO}_{4}$, which is lixiviated, resulting, over time, in reduced $\mathrm{Na}^{+}$levels in the soil (BARROS et al., 2004; LIYUAN et al., 2013).

Significant effects were observed at the $1 \%$ and $5 \%$ significance levels $(p<0.01$ and $p<0.05$ ) for the interaction between the soil conditioners and the castor bean cultivars for all analyzed variables, except for the foliar surface ratio, which showed only an isolated effect depending on the soil conditioners and on the cultivars (Table 5). It is believed that foliar growth is representative of higher plant vigor due to a larger area available for the production of photoassimilates. Our results indicate that the soil conditioners have different effects on the soil, reflected in the castor bean tree cultivars due to their distinct responses to salts, and are in accordance with the conclusions of Flowers and Flowers (2005) that plants of the same species can show different responses to salinity (Table 5).

Table 5. Summary of the analysis of variance of the variables height, stem diameter, height/diameter ratio, number of leaves, foliar surface, foliar surface ratio, dry matter of the aerial part, root dry matter, total dry matter, and root/ aerial part ratio for castor bean cultivars grown in a saline-sodic soil with added chemical and organic conditioners and washed, and in a non-saline soil. Catolé do Rocha - PB, 2014.

\begin{tabular}{|c|c|c|c|c|c|c|c|c|c|c|c|}
\hline \multirow[t]{2}{*}{ SV } & \multirow[t]{2}{*}{$\mathrm{DF}$} & \multicolumn{10}{|c|}{ QUADRATIC MEAN } \\
\hline & & $\mathrm{H}$ & SD & HDR & NL & FS & FSR & DMAP & RDM & TDM & RAPR \\
\hline $\mathrm{C}$ & 4 & $31.11 * *$ & $2.13 * *$ & $15.85 * *$ & $11.78 * *$ & $17747.11^{* *}$ & $220.65 * *$ & $6.09 * *$ & $0.87 * *$ & $11.54 * *$ & $0.01 * *$ \\
\hline $\mathrm{V}$ & 1 & $3.38^{* *}$ & $0.80 * *$ & $4.33^{\mathrm{NS}}$ & $0.02^{\mathrm{NS}}$ & $3175.52 * *$ & $831.19^{* *}$ & $0.12 *$ & $0.08 * *$ & $0.002^{\mathrm{NS}}$ & $0.07 * *$ \\
\hline $\mathrm{C} \times \mathrm{V}$ & 4 & $3.55^{* *}$ & $0.13 * *$ & $11.11^{* *}$ & $0.58 * *$ & $261.87 * *$ & $88.04^{\mathrm{NS}}$ & $0.24 * *$ & $0.01 * *$ & $0.25 * *$ & $0.005^{*}$ \\
\hline ERROR & 27 & 0.44 & 0.02 & 1.91 & 0.18 & 39.82 & 38.73 & 0.02 & 0.003 & 0.03 & 0.001 \\
\hline $\mathrm{CV}$ & & 21.59 & 16.92 & 38.29 & 10.53 & 7.36 & 12.34 & 10.10 & 10.21 & 8.44 & 13.15 \\
\hline
\end{tabular}


The vertical growth of the castor bean cultivars varied as a function of the different soil conditioners added to the saline-sodic soil, with the highest growths observed for the treatments involving the application of chalk associated with biofertilizers, but the values were not significantly different from those observed in the non-saline soil, according to the Tukey's test at a 5\% significance level (Table 5). The BRS Paraguaçu cultivar grew bigger than the BRS Nordestina cultivar, except in the saline-sodic soil with added biofertilizer. The more prominent vertical growth of the latter in these conditions may indicate that this cultivar adjusts better to sodicity than the BR Paraguaçu cultivar, since, in the described treatment, the SAR and the ESP remained very high, representing the highly sodic soil profile (RICHARDS, 1954; BARROS et al., 2005), as shown in Table 4.

As observed in vertical growth, the treatment with chalk and biofertilizer promoted the highest stem growth on both cultivars, but the observed values were not different from those obtained for plants grown in non-saline soil (Table 6), and the smallest stem diameter was recorded for the plants grown in the sodic saline soil with added biofertilizer. The smaller stem diameter (Table 4) reflects low levels of calcium in the bovine biofertilizer (Table 2), which could substitute sodium in the saline-sodic soil and evidences the low efficiency of the organic compost in the reduction of sodicity of soils rich in exchangeable sodium, as concluded by Miranda et al. (2011) and Sá et al. (2013a) when working with saline-sodic soil treated with chalk and organic matter. Among the cultivars, the BRS Nordestina showed the largest diameters in all evaluated treatments.

The height/stem diameter ratio reflects the equilibrium state of the plant growth; that is, plants with sufficient growth are tolerant to abiotic stresses, such as soil salinity. The lowest values for the height/diameter ratio were found for plants from both cultivars grown in the saline-sodic soil with or without biofertilizer in comparison with plants cultivated in the non-saline soil (Table 6). Our results show that these treatments caused the most stress to plants of both cultivars. The plants grown in soil treated with chalk and biofertilizers were the closest to the control plants that were grown in non-saline soil (Table 6), indicating the beneficial effect of chalk and addition of biofertilizer on plant growth (LEITE et al., 2007; SÁ et al., 2013b).

Although lower than the values observed for plants cultivated in the non-saline soil, the number of leaves produced and the foliar surface were higher in the plants grown in the saline-sodic soil with added chalk and biofertilizer. Furthermore, the BRS Nordestina cultivar produced more leaves when grown in soil without any conditioners when compared to the BRS Paraguaçu cultivar, showing more tolerance to the adverse conditions imposed by sodicity (Table 6).

The biggest foliar surface growth was observed for plants of the BRS Nordestina cultivar compared to the BRS Paraguaçu cultivar in all evaluated treatments. This condition is associated with a higher photosynthetic efficiency. According to Taiz and Zeiger (2013), larger foliar surfaces contain more vacuoles, which are responsible for the allocation of electrolytes and therefore minimize the deleterious effects of salinity.

The foliar surface ratio represents the assimilatory surface per unit of dry matter, and evidences the efficiency in the assimilation of photosynthetic products, even for plants cultivated in environments compromised by the effects of saline stress, especially due to the osmotic effect. According to Flowers and Flowers (2005), the osmotic effect is the main agent of the deleterious effects of salinity. When grown in the saline-sodic soil with added biofertilizer, the BRS Nordestina cultivar showed the highest foliar surface ratio, which was probably an attempt by the plant to maximize the photosynthetic process as a mechanism to deal with stress. The lowest foliar surface ratios were recorded for the BRS Paraguaçu cultivar, as observed for the other evaluated variables, showing its higher sensitivity to saline stress (Table 6). 
Table 6. Tukey's range test on the variables height (AT), stem diameter (SD), height/diameter ratio (HDR), number of leaves (NL), foliar surface (FS), foliar surface ratio (FSR), dry matter of the aerial part (DMAP), root dry matter (RDM), total dry matter (TDM), and root/aerial part ratio (RAPR). Areas of castor bean growth in non-saline soil and saline-sodic soil with added chemical and organic conditioners with washing.

\begin{tabular}{ccccccc}
\hline \multirow{2}{*}{ Treatments } & \multicolumn{2}{c}{$\begin{array}{c}\text { Height }-\mathrm{H}(\mathrm{cm}) \\
\text { Cultivars }\end{array}$} & \multicolumn{2}{c}{$\begin{array}{c}\text { Diameter }-\mathrm{SD}(\mathrm{mm}) \\
\text { Cultivars }\end{array}$} & \multicolumn{2}{c}{$\begin{array}{c}\text { Height/diameter ratio (HDR) } \\
\text { Cultivars }\end{array}$} \\
\cline { 2 - 6 } & BRS & BRS & BRS & BRS & BRS & BRS \\
& Nordestina & Paraguaçu & Nordestina & Paraguaçu & Nordestina & Paraguaçu \\
\hline $\mathrm{SSC}$ & $0.83 \mathrm{Ca}$ & $0.87 \mathrm{Ca}$ & $0.69 \mathrm{Ca}$ & $0.54 \mathrm{BCa}$ & $1.22 \mathrm{Ba}$ & $1.60 \mathrm{Ca}$ \\
$\mathrm{SS}+\mathrm{B}$ & $1.93 \mathrm{BCa}$ & $0.73 \mathrm{Cb}$ & $0.30 \mathrm{Da}$ & $0.24 \mathrm{Ca}$ & $6.91 \mathrm{Aa}$ & $3.78 \mathrm{ABb}$ \\
$\mathrm{SS}+\mathrm{C}$ & $3.10 \mathrm{ABa}$ & $3.36 \mathrm{Ba}$ & $0.94 \mathrm{Ca}$ & $0.77 \mathrm{Ba}$ & $3.35 \mathrm{Ba}$ & $4.40 \mathrm{Aba}$ \\
$\mathrm{SS}+\mathrm{C}+\mathrm{B}$ & $4.26 \mathrm{Ab}$ & $6.00 \mathrm{Aa}$ & $1.53 \mathrm{Ba}$ & $1.29 \mathrm{Ab}$ & $2.78 \mathrm{Ba}$ & $4.61 \mathrm{Aa}$ \\
$\mathrm{NSS}$ & $3.86 \mathrm{Ab}$ & $5.93 \mathrm{Aa}$ & $1.87 \mathrm{Aa}$ & $1.14 \mathrm{Ab}$ & $2.11 \mathrm{Bb}$ & $5.26 \mathrm{Aa}$ \\
\hline
\end{tabular}

\begin{tabular}{|c|c|c|c|c|c|c|}
\hline \multirow{4}{*}{ Treatments } & \multirow{2}{*}{\multicolumn{2}{|c|}{ Number of leave - NL }} & \multirow{2}{*}{\multicolumn{2}{|c|}{$\begin{array}{c}\text { Foliar surface }-\mathrm{FS}\left(\mathrm{cm}^{2}\right) \\
\text { Cultivars }\end{array}$}} & \multirow{2}{*}{\multicolumn{2}{|c|}{$\begin{array}{c}\text { Foliar surface ratio (FSR) } \\
\text { Cultivars }\end{array}$}} \\
\hline & & & & & & \\
\hline & \multirow{2}{*}{$\begin{array}{c}\text { BRS } \\
\text { Nordestina }\end{array}$} & \multirow{2}{*}{$\begin{array}{c}\text { BRS } \\
\text { Paraguaçu }\end{array}$} & BRS & BRS & BRS & BRS \\
\hline & & & Nordestina & Paraguaçu & Nordestina & Paraguaçu \\
\hline $\mathrm{SSC}$ & $3.3 \mathrm{Ba}$ & $2.5 \mathrm{Db}$ & $54.49 \mathrm{Da}$ & $36.91 \mathrm{Db}$ & $44.77 \mathrm{Ba}$ & $40.47 \mathrm{Aa}$ \\
\hline $\mathrm{SS}+\mathrm{B}$ & $3.0 \mathrm{Ba}$ & $3.0 \mathrm{Da}$ & 46.92Da & $35.72 \mathrm{Db}$ & 65.96Aa & $46.89 \mathrm{Ab}$ \\
\hline $\mathrm{SS}+\mathrm{C}$ & $3.8 \mathrm{Ba}$ & $4.0 \mathrm{Ca}$ & $82.26 \mathrm{Ca}$ & $70.99 \mathrm{Cb}$ & $56.38 \mathrm{ABa}$ & $45.08 \mathrm{Ab}$ \\
\hline $\mathrm{SS}+\mathrm{C}+\mathrm{B}$ & $5.0 \mathrm{Aa}$ & $5.0 \mathrm{Ba}$ & $117.61 \mathrm{Ba}$ & $106.27 \mathrm{Bb}$ & $53.14 \mathrm{ABa}$ & 44.34Aa \\
\hline NSS & $5.3 \mathrm{Aa}$ & $6.0 \mathrm{Aa}$ & $171.88 \mathrm{Aa}$ & $134.18 \mathrm{Ab}$ & $54.71 \mathrm{ABa}$ & $52.60 \mathrm{Aa}$ \\
\hline \multirow{3}{*}{ Treatments } & \multicolumn{3}{|c|}{ Dry matter of the aerial part - DMAP $(\mathrm{g})$} & \multicolumn{3}{|c|}{ Root dry matter - RDM (g) } \\
\hline & \multicolumn{3}{|c|}{ Cultivars } & \multicolumn{3}{|c|}{ Cultivars } \\
\hline & \multicolumn{2}{|c|}{ BRS Nordestina } & BRS Paraguaçu & \multicolumn{2}{|c|}{ BRS Nordestina } & BRS Paraguaçu \\
\hline $\mathrm{SSC}$ & \multicolumn{2}{|c|}{$1.26 \mathrm{Ca}$} & $0.90 \mathrm{Cb}$ & \multicolumn{2}{|c|}{$0.31 \mathrm{Da}$} & $0.27 \mathrm{Da}$ \\
\hline $\mathrm{SS}+\mathrm{B}$ & \multicolumn{2}{|c|}{$0.71 \mathrm{Da}$} & $0.77 \mathrm{Ca}$ & \multicolumn{2}{|c|}{$0.19 \mathrm{Db}$} & $0.31 \mathrm{Da}$ \\
\hline $\mathrm{SS}+\mathrm{C}$ & \multicolumn{2}{|c|}{$1.46 \mathrm{Ca}$} & $1.59 \mathrm{Ba}$ & \multicolumn{2}{|c|}{$0.45 \mathrm{Cb}$} & $0.55 \mathrm{Ca}$ \\
\hline $\mathrm{SS}+\mathrm{C}+\mathrm{B}$ & \multicolumn{2}{|c|}{$2.21 \mathrm{Ba}$} & 2.42Aa & \multicolumn{2}{|c|}{$0.71 \mathrm{Bb}$} & $0.80 \mathrm{Ba}$ \\
\hline NSS & \multicolumn{2}{|c|}{$3.15 \mathrm{Aa}$} & $2.55 \mathrm{Ab}$ & $0.94 \mathrm{~A}$ & & $1.13 \mathrm{Aa}$ \\
\hline \multirow{3}{*}{ Treatments } & \multicolumn{3}{|c|}{ Total dry matter - TDM (g) } & \multicolumn{3}{|c|}{ Root/aerial part ratio - RAPR } \\
\hline & \multicolumn{3}{|c|}{ Cultivars } & \multicolumn{3}{|c|}{ Cultivars } \\
\hline & BRS I & destina & BRS Paraguaçu & BRS Norc & & BRS Paraguaçu \\
\hline $\mathrm{SSC}$ & \multicolumn{2}{|c|}{$1.57 \mathrm{Ca}$} & $1.17 \mathrm{Db}$ & $0.23 \mathrm{~A}$ & & $0.30 \mathrm{Ca}$ \\
\hline $\mathrm{SS}+\mathrm{B}$ & \multirow{2}{*}{\multicolumn{2}{|c|}{$0.90 \mathrm{Da}$}} & $1.08 \mathrm{Da}$ & $0.28 \mathrm{~A}$ & & $0.41 \mathrm{ABa}$ \\
\hline $\mathrm{SS}+\mathrm{C}$ & & & $2.15 \mathrm{Ca}$ & $0.30 \mathrm{~A}$ & & $0.37 \mathrm{ABCa}$ \\
\hline $\mathrm{SS}+\mathrm{C}+\mathrm{B}$ & & $\mathrm{Bb}$ & $3.22 \mathrm{Ba}$ & $0.32 \mathrm{~A}$ & & $0.33 \mathrm{BCa}$ \\
\hline NSS & & & 3.69Ab & $0.29 \mathrm{~A}$ & & $0.44 \mathrm{Aa}$ \\
\hline
\end{tabular}

* Non-saline soil (NSS); Saline - sodic soil without conditioners (SSC); Saline - sodic soil plus biofertilizer at $10 \%$ of the soil volume (SS+B); Saline - sodic soil plus chalk at $100 \%$ of chalk requirement (SS+C), Saline - sodic soil plus chalk and biofertilizer $(\mathrm{SS}+\mathrm{C}+\mathrm{B}) .{ }^{*}$ Different capital letters in the columns refer to significantly different treatments for soil correction, and different lowercase letters in the rows indicate significantly different cultivar response according to the Tukey's test at the $5 \%$ significance level. 
The dry matter of the aerial part and the roots of the castor bean cultivars varied according to the soil conditioners applied to the saline-sodic soil, where the treatment with chalk and biofertilizer provided the better yield, and the treatment with biofertilizer alone resulted in the lowest growth for both cultivars (Table 6). When cultivated in soil with chalk and biofertilizers, the BRS Paraguaçu cultivar showed dry matter accumulation similar to that observed in plants cultivated in non-saline soil. The dry matter accumulation in the roots of this cultivar was higher than that observed for the BRS Nordestina cultivar in all treatments, except for the growth in salinesodic soil without any conditioners (Table 6). In some species, expansion of the radicular system is an indicator of salt stress tolerance. In the salinesodic soils, the soil conditioner chalk applied in combination with biofertilizer stimulates physical improvement of the soil, resulting in a larger porous space for the radicular growth and absorption of water and nutrients by the plants, with consequent physiological and nutritional adjustments that enable increased plant growth (FLOWERS; FLOWERS, 2005; TAIZ; ZEIGER, 2013).

The data for total dry matter, showing a better performance for the BRS Nordestina, confirm a higher efficiency of chalk associated with biofertilizer, as also observed for other variables (Table 6), indicating a positive effect on soil correction by chalk and an improvement of plant nutrition by the biofertilizer.

Only the BRS Paraguaçu cultivar responded to the effects of the evaluated treatments regarding the root/aerial part ratio, in which the growth in soil without conditioners, or with the addition of chalk only, was similar to the growth observed under control conditions (Table 6). As observed for the root dry matter, this suggests that the increase in the root/aerial part ratio is a reaction by the plant to expand the radicular system to assure higher efficiency of water and nutrient absorption. This increase also depends on improvements in the physical and chemical quality of the soil that results from the application of conditioners, even though they did not have an effect on the total dry matter.

\section{Conclusions}

The use of soil conditioners reduced the salinity and the sodicity of the saline-sodic soil.

The application of chalk, with or without the addition of biofertilizers, promoted the best FSR and ESP outcomes, with respective values lower than $13 \mathrm{mmol}_{\mathrm{c}} \cdot \mathrm{L}^{-1}$ and $15 \%$. Biofertilizer alone does not contribute to the mitigation of sodicity. The most efficient treatment in correcting sodicity and plant growth was the application of chalk together with biofertilizer. Under the evaluated conditions, the BRS Nordestina cultivar showed a higher tolerance to sodicity than the BRS Paraguaçu cultivar.

\section{References}

BABITA, A. M.; MAHESWARIB, M.; RAO, A; SHANKERB, L. M.; ARUN, K.; GANGADHAR, R. D. Osmotic adjustment, drought tolerance and yield in castor (Ricinus communis L.) hybrids. Journal Environmental and Experimental Botany, New York, v. 69, n. 3, p. 243249, 2010.

BARROS, M. F. C.; FONTES, M. P. F.; ALVAREZ, V. H.; RUIZ, H. A. Aplicação de gesso e calcário na recuperação de solos salino-sódicos do estado de Pernambuco. Revista Brasileira de Engenharia Agrícola e Ambiental, Campina Grande, v. 9, n. 3, p. 320-326, 2005.

Recuperação de solos afetados por sais pela aplicação de gesso de jazida e calcário do Nordeste do Brasil. Revista Brasileira de Engenharia Agrícola e Ambiental, Campina Grande, v. 8, n. 1, p. 59-64, 2004.

BONAGEMA, G. K.; CAMPOS, D. V. B.; CALDERANO, S. B.; TEIXEIRA, W. G.; VIANA, J. H. M. Manual de métodos de análise de solos. 2. ed. Rio de Janeiro: Embrapa Solos, 2011. 230 p. (Documentos / Embrapa Solos, 132).

CAVALCANTE, L. F.; COSTA, J. R. M.; OLIVEIRA, F. K. D.; CAVALCANTE, I. H. L.; ARAÚJO, F. A. R. Produção do maracujazeiro-amarelo irrigado com água salina em covas protegidas contra perdas hídricas. Irriga, Botucatu, v. 10, n. 3, p. 229-240, 2005. 
EMPRESA BRASILEIRA PESQUISA AGROPECUÁRIA - EMBRAPA. Sistema brasileiro de classificação de solos. 2. ed. Rio de Janeiro: Embrapa Solos, 2006. 306 p.

FERREIRA, D. F. Sisvar: a computer statistical analysis system. Ciência e Agrotecnologia, Lavras, v. 35, n. 6, p. 1039-1042, 2011.

FLOWERS, T. J.; FLOWERS, S. A. Why does salinity pose such a difficult problem for plant breeders? Agricultural Water Management, Oxford, v. 78, n. 1, p. 15-24, 2005.

FREIRE, M. B. S.; FREIRE, F. J. Fertilidade do solo e seu manejo em solos afetados por sais. In: NOVAIS, R. F.; ALVAREZ V. V. H.; BARROS, N. F.; FONTES, R. L. F.; CANTURUTTI, B.; NEVES, J. C. L. Fertilidade do solo. Viçosa: SBCS, 2006, p. 929-954.

LEITE, E. M.; CAVALCANTE, L. F.; DINIZ, A. A.; SANTOS, R. V.; ALVES, G. S.; LUCENA, CAVALCANTE, I. H. L. Correção da sodicidade de dois solos irrigados em resposta à aplicação de gesso agrícola. Irriga, Botucatu, v. 12, n. 2, p. 168-176, 2007.

LEITE, E. M.; DINIZ, A. A.; CAVAlCANTE, L. F.; RAIJ, H. G.; CAMPOS, V. B. Redução da sodicidade em solo irrigado com a utilização de ácido sulfúrico e gesso agrícola. Revista Caatinga, Mossoró, v. 23, n. 2, p. 110116, 2010.

LI-YUAN, L.; YU-PENG, W.; ZHEN-JUN, S.; YANMENG, B. Effect of organic fertilizer on growth of castor bean seedling under saline sodic soil. Journal of China Agricultural University, Beijing, v. 18, n. 3, p. 73-80, 2013.

MENEZES JÚNIOR, J.C.; SANTOS, R. V.; SOBRINHO, W. N.; SOUTO, J. S. Emprego de acondicionadores químicos, fontes e doses de fósforo em solo degradado por sais na produção do milheto (PennisetumglaucumL.). Revista Acadêmica Ciências Agrárias e Ambientais, Curitiba, v. 8, n. 1, p. 39-45, 2010.

MIRANDA, M. A.; OLIVEIRA, E. E. M.; SANTOS, K. C. F.; FREIRE, M. B. G. S.; ALMEIDA, B. G. Condicionadores químicos e orgânicos na recuperação de solo salino-sódico em casa de vegetação. Revista Brasileira de Engenharia Agrícola e Ambiental, Campina Grande, v. 15, n. 5, p. 484-490, 2011.

MUNNS, R.; TESTER, M. Mechanisms of salinity tolerance. Annual Review of Plant Biology, Palo Alto, $\mathrm{v}$ 59, n. 1, p. 651-681, 2008.

NEVES, A. L. R.; LACERDA, C. F.; GUIMARÃES, F. V. A.; HERNANDEZ, F. F. F.; SILVA, F. B.; PRISCO, J. T.; GHEYI, H. R. Acumulação de biomassa e extração de nutrientes por plantas de feijão-de-corda irrigadas com água salina em diferentes estádios de desenvolvimento. Ciência Rural, Santa Maria, v. 39, n. 3, p. 758-765, 2009.

NUNES, J. C.; CAVALCANTE, L. F.; REBEQUI, A. M.; LIMA NETO, J.; DINIZ, A. D.; SILVA, J. J. M.; BREHM, M. A. S. Formação de mudas de noni sob irrigação com águas salinas e biofertilizante bovino no solo. Revista de Engenharia Ambiental, Santo do Pinhal, v. 6, n. 2, p. 451-463, 2009.

PAIXÃO, F. J. R.; BELTRÃO, N. E. M.; AZEVEDO, C. A. V.; PIMENTEL, J. V. F.; CARlos, J. A. P. Production and yield components of castor bean BRS energia in function of different levels of irrigation and nitrogen organic fertilization. Brazilian Journal of Applied Technology for Agricultural Science, Guarapuava, v. 6, n. 3, p. 27-37, 2013.

QADIR, M.; OSTER, J. D.; SCHUBERT, S.; NOBLE, A. D.; SAHRAWAT, K. L. Phytoremediation of Sodic and Saline-Sodic Soils. Advances in Agronomy, New York, v. 96, n. 1, p. 197-247, 2007.

RICHARDS, L. A. Diagnosis and improvement of saline and alkali soils. Washington: US Department of Agriculture, 1954. 160 p. (USDA Agricultural Handbook, 60).

SÁ, F. V. S.; ARAÚJO, J. L.; NOVAIS, M. C.; SILVA, A. P.; PEREIRA, F. H. F.; LOPES, K. P. Crescimento inicial de arbóreas nativas em solo salino-sódico do Nordeste brasileiro tratado com acondicionadores. Revista Ceres, Viçosa, v. 60, n. 3, p. 388-396, 2013a.

SÁ, F. V. S.; BRITO, M. E. B.; MELO, A. S.; ANTÔNIO NETO, P.; FERNANDES, P. D.; FERREIRA, I. B. Produção de mudas de mamoeiro irrigadas com água salina. Revista Brasileira Engenharia Agrícola Ambiental, Campina Grande, v. 17, n. 10, p. 1047-1054, 2013b.

SANTOS, C. E. R. S.; BEZERRA, R. V.; FREITAS, A. D. S.; SEIDO, S. L.; MARTINS, L. M. V.; RUMJANEK, N. G.; XAVIER, G. R. Modificações de vasos de Leonard com garrafas tipo Pet. Seropértica: Embrapa, 2009. 4 p. (Comunicado técnico, 124).

SANTOS, M. F. G.; OLIVEIRA, F. A.; CAVALCANTE, L. F.; MEDEIROS, J. F. de; SOUZA, C. C. Solo sódico tratado com gesso agrícola, composto de lixo urbano e vinhaça. Revista Brasileira de Engenharia Agrícola Ambiental, Campina Grande, v. 9, n. 3, p. 307-313, 2005.

SOUSA, F. Q.; ARAÚJO, J. L.; SILVA, A. P.; PEREIRA, F. H. F.; SANTOS, R. V.; LIMA, G. S. Crescimento e respostas fisiológicas de espécies arbóreas em solo salinizado tratado com acondicionadores. Revista Brasileira de Engenharia Agrícola e Ambiental, Campina Grande, v. 16, n. 2, p. 173-181, 2012. 
SOUZA, A. S.; TÁVORA, F. J. A. F.; PITOMBEIRA, J. B.; BEZERRA, F. M. L. Épocas de plantio e manejo da irrigação para a mamoneira. II - crescimento e produtividade. Revista Ciência Agronômica, Fortaleza, v. 38, n. 4, p. 422-429, 2007.

SUAREZ, D. L. Sodic soil reclamation: modelling and field study. Australian Journal Soil Research, Melborne, v 39, n. 1, p 1225-1246, 2001.
TAIZ, L.; ZEIGER, E. Fisiologia vegetal. 4. ed. Porto Alegre: Artmed, 2013. 853 p.

WENDT, C. W. Use of a relationship between leaf length and leaf area of cotton (Gossypium hirsutum L.), castor (Ricinus communis L.), and Sorghum (Sorghum vulgare L.). Agronomy Journal, Madison, v. 59, n. 5, p. 485-487, 1967. 